\title{
$\begin{array}{llllllllllllllll}\mathbf{S} & \mathbf{T} & \mathbf{U} & \mathbf{D} & \mathbf{I} & \mathbf{A} & \mathbf{I} & \mathbf{M} & \mathbf{A} & \mathbf{T} & \mathbf{E} & \mathbf{R} & \mathbf{I} & \mathbf{A} & \mathbf{L} & \mathbf{Y}\end{array}$ \\ KWARTALNIK HISTORII KULTURY MATERIALNEJ 67 (4), 2019 \\ PL ISSN 0023-5881 \\ www.iaepan.edu.pl \\ DOI: 10.23858/KHKM67.2019.4.001
}

\author{
Michat Starski
}

\section{Puck i Lębork. Dwa warianty kształtowania się wytwórczości garncarskiej w małych miastach Pomorza Gdańskiego w późnym średniowieczu}

\author{
Słowa kluczowe: Puck, Lębork, garncarstwo, ceramika, późne średniowiecze, Pomorze \\ Gdańskie \\ Key words: Puck, Lębork, pottery handicraft, ceramics, late Middle Ages, Gdańsk \\ Pomerania
}

Proces kształtowania się ośrodków miejskich, przypadający na ziemiach polskich na późne średniowiecze, od dawna wzbudza zainteresowanie badaczy różnych specjalności. Wynika to bez wątpienia z wielowątkowości tej problematyki, która angażuje zarówno historyków, urbanistów, architektów, jak i archeologów. Dla tych ostatnich jednym z istotniejszych problemów badawczych są przemiany w kulturze materialnej, towarzyszące kształtowaniu się społeczności miejskich w procesie lokacji. Dzięki intensywnym pracom archeologicznym prowadzonym w ostatnich dziesięcioleciach możliwa jest już nie tylko ogólna charakterystyka zmian, jakim podlegał asortyment używanych dóbr, ale rekonstrukcja tego procesu w skali regionalnej, a nawet lokalnej. W rezultacie źródła archeologiczne umożliwiają włączenie w zakres rozważań nowych wątków badawczych dotyczących charakteru i intensywności procesów towarzyszących urbanizacji.

Jednym z często poruszanych tematów jest kwestia przemian w wytwórczości garncarskiej. Na podstawie wyników analizy masowych zbiorów znalezisk wskazać można cechy, jakie miała ona przed oraz po lokacji w zakresie zróżnicowania gatunków i rodzajów używanych naczyń oraz stosowanych technik produkcji. W rezultacie tak ukierunkowanych studiów uzasadnione staje się określenie źródeł kształtowania się lokalnej produkcji oraz stopnia, w jakim uwzględniała ona elementy tradycyjne oraz nowe ${ }^{1}$. Zagadnienia te umożliwiają podjęcie badań nad różnymi wariantami bądź nawet modelami adaptacji i rozwoju lokalnej wytwórczości, co stanowi temat niniejszego artykułu.

Dla znacznej części badaczy problematyka zmian zachodzących w produkcji i asortymencie naczyń ceramicznych na etapie powstawania miast nie jest pierwszoplanowa. Rzemiosło garncarskie nie należało bowiem do kluczowych w miejskiej gospodarce. Rezultaty analiz masowych zbiorów ceramiki z wybranych ośrodków wskazują jednak, że ich znaczenie dla odzwierciadlania procesów przemian społecznych i gospodarczych towarzyszących lokacji jest niedoceniane. Dzięki studiom nad reprezentatywną dla badanego ośrodka podstawą źródłową możliwe jest np. uzyskanie danych dotyczących przybliżonej chronologii zasiedlania poszczególnych części miast ${ }^{2}$, choć wyroby ceramiczne nie są źródłem precyzyjnie datującym nawarstwienia ${ }^{3}$. Ustalenia dotyczące zróżnicowania struktury i asortymentu używanych wy-

1 M.in. Kruppé J. 1967; Kruppé J. 1981; Dzieduszycki W. 1982; Rębkowski M. 1995; Poliński D. 1996; Poliński D. 2007; Rzeźnik P. 1998; Trzeciecki M. 2009; Trzeciecki M. 2016; Starski M. 2009; Starski M. 2016 a.

2 Rębkowski M. 2001, s. 172-176.

3 Starski M. 2016a, s. 17. 


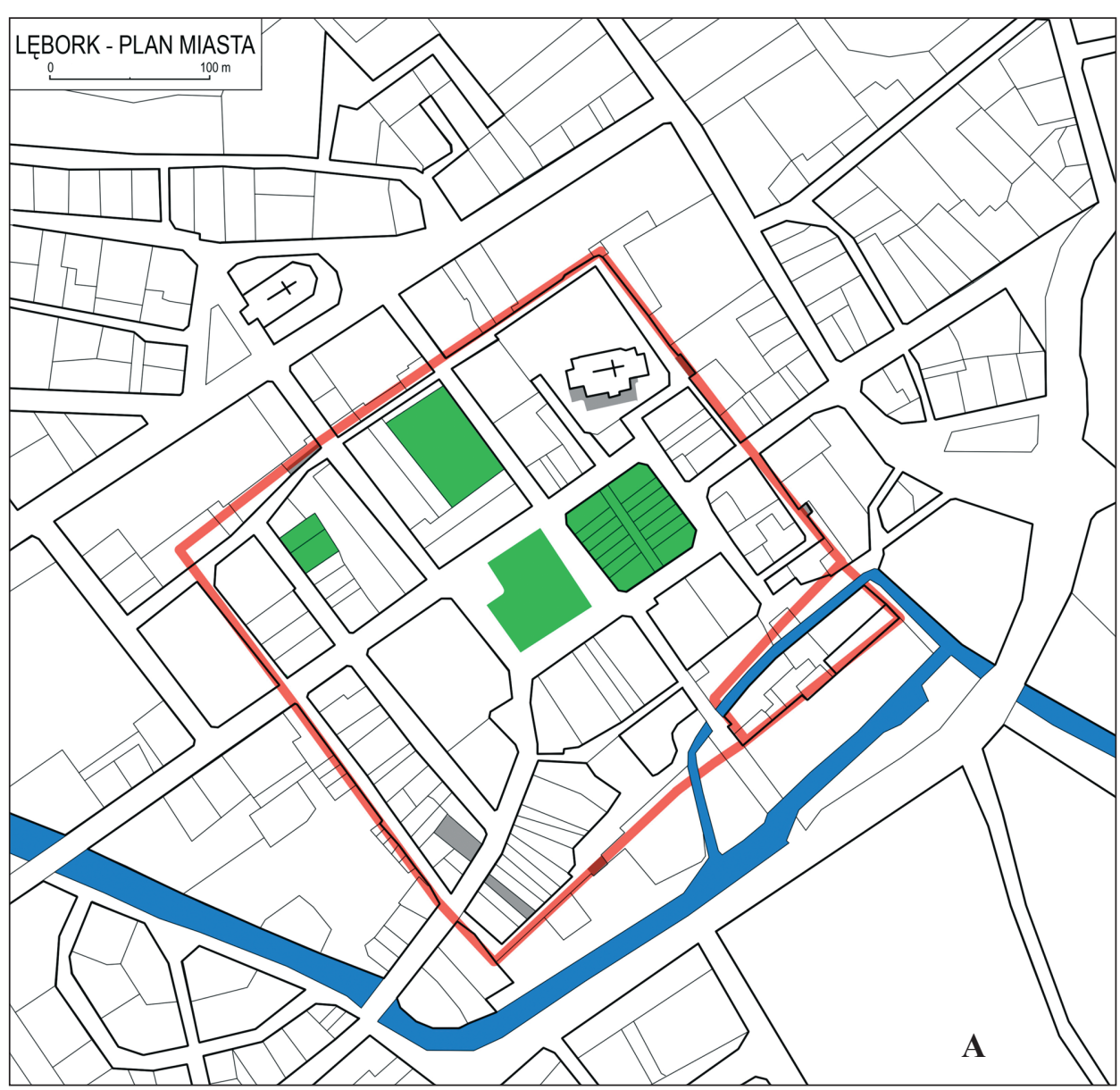

robów, świadczyć mogą o różnicach majątkowych lub społecznych (czasem odczytywanych jako etniczne), kontaktach handlowych lub innych, nierozpoznanych jeszcze zagadnieniach związanych z procesem kształtowania się miasta. Wyników analiz nie należy przyjmować jednoznacznie, ale uznać można, że w obliczu niedoboru innych danych wyroby garncarskie stanowią często jedyne, choć specyficzne, źródło informacji o procesach zachodzących w trakcie kształtowania się miast lokacyjnych.

Proces krystalizowania się wytwórczości garncarskiej w nowo zakładanych miastach zaprezentuję na przykładzie dwóch małych ośrodków położonych na Pomorzu Gdańskim — Pucka i Lęborka. Obydwa powstały w podobnym czasie, miały zbliżoną wielkość oraz rangę w administracji państwa Zakonu Krzyżackiego. Mimo to w dziesięcioleciach po lokacji tamtejsza produkcja garncarska miała odmienną strukturę. Pozwala to zrekonstruować dwa różne warianty kształtowania się omawianej dziedziny wytwórczości.

Tłem historycznym dla powstania omawianych miast jest sytuacja polityczna Pomorza Gdańskiego. Po okresie niezależności księstwa wschodniopomorskiego w XIII w. zostało ono zajęte przez Brandenburczyków (w 1308 r.), którzy następnie zostali wyparci przez Zakon Krzyżacki. W rezultacie tej interwencji ziemie księstwa zostały przyłączone do władztwa tery- 


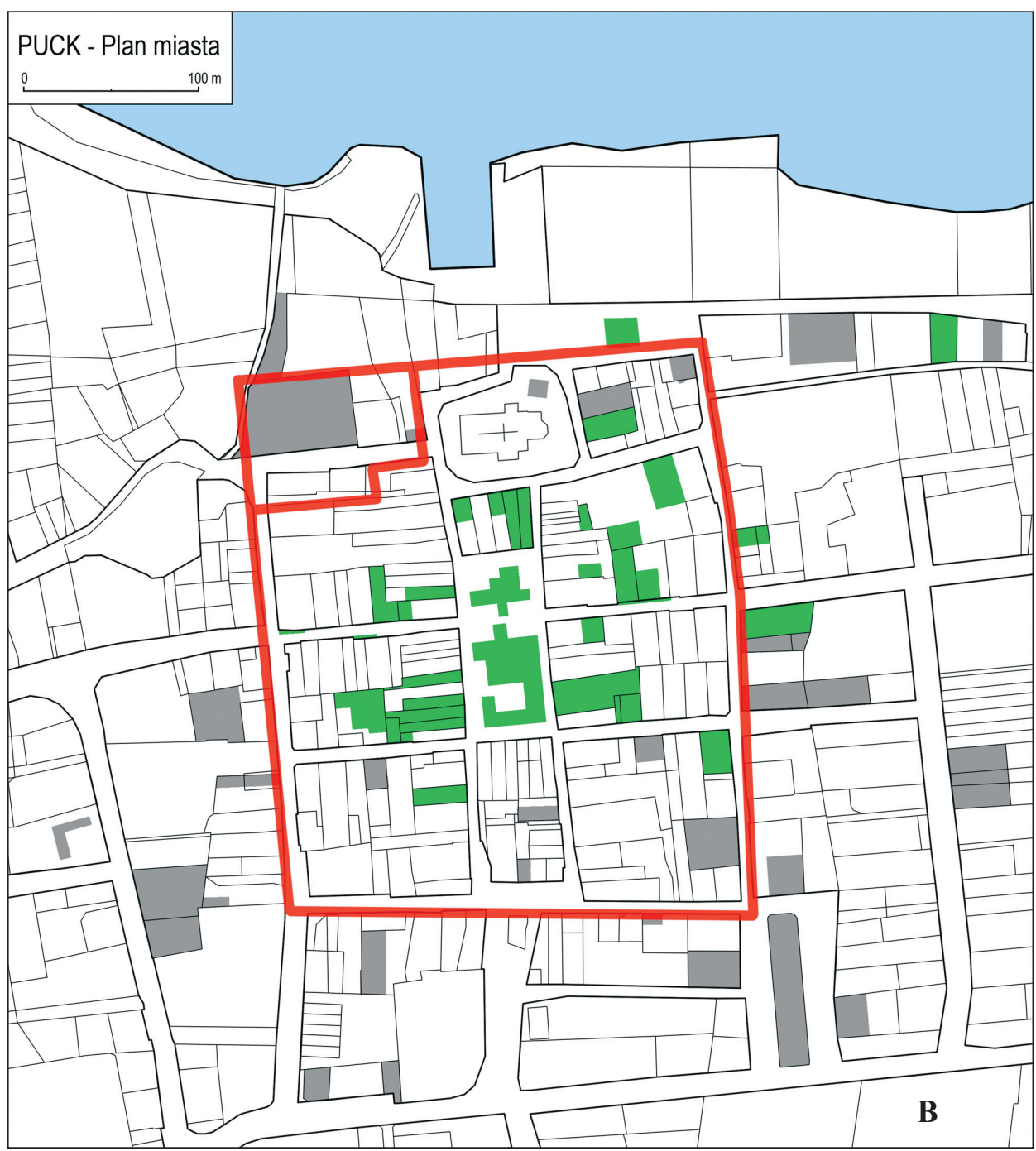

Ryc. 1. Plan miasta lokacyjnego w Lęborku (A) i Pucku (B). Na zielono oznaczono miejsca, z których znaleziska uwzględniono w podstawie źródłowej (oprac. M. Starski)

Fig. 1. Map of the chartered town in Lębork (A) and Puck (B). The places where the finds were included in the source base are marked in green (prepared by M. Starski)

torialnego Zakonu w Prusach ${ }^{4}$. Wydarzenia te zahamowały proces kształtowania się ośrodków miejskich, z których najstarsze uzyskały przywileje lokacyjne już w XIII stuleciu, a niepewna sytuacja polityczna między Zakonem a Królestwem Polskim opóźniła akcję formowania nowych miast $^{5}$. Do unormowania sytuacji doszło w końcu lat trzydziestych XIV w., a w roku 1343 do zawarcia pokoju kaliskiego. W rezultacie do końca lat pięćdziesiątych XIV w. lokowanych było

\footnotetext{
4 Jasiński K. 1978; Biskup M., Labuda G. 1986, s. 255-258; Śliwiński B. 2006, s. 76-101; 2009.

${ }^{5}$ Lalik T. 1965; Biskup M. 1980; Grzegorz M. 1988; Grzegorz M. 2007, s. 120-125.
} 
12 mniejszych miast i Gdańsk, zaś sieć miejską Pomorza Gdańskiego dopełniły cztery młodsze ośrodki powstałe do początku XV w. ${ }^{6}$

Lębork i Puck lokowane były w pierwszym etapie kształtowania przez Krzyżaków sieci miejskiej w północnej części Pomorza Gdańskiego, na obszarze zasiedlonym przez miejscową ludność kaszubską, lecz uformowanie się tych ośrodków związane było z napływem nowych osadników spoza regionu? ${ }^{7}$ W przypadku Lęborka, któremu akt lokacyjny nadano 6 stycznia 1341 r., nastąpiło to wraz z przeniesieniem dawnego centrum osadniczego w nowe miejsce ${ }^{8}$. Ziemie te w okresie wczesnośredniowiecznym podlegały kasztelanii białogardzkiej, lecz zniszczony na początku XIV w. ośrodek grodowy opuszczono9 ${ }^{9}$, a nowe lokalne centrum miejskie przeniesiono ok. $10 \mathrm{~km}$ na południe, w miejsce położone przy przeprawie przez bagnistą dolinę Łeby $^{10}$. Wynikało to z przesunięcia nieco na południe (w pas pradoliny Łeby) dawnego szlaku wiodącego przez Białogardę w kierunku Słupska i Pomorza Zachodniego ${ }^{11}$. Nowy ośrodek o powierzchni ok. 9 hektarów uzyskał regularny czworoboczny kształt z kwadratowym rynkiem zlokalizowanym pośrodku (ryc. 1A). Jedyną nieregularnością w rozplanowaniu miasta była ulica wychodząca z rynku łukowato w kierunku południowo-zachodnim (obecnie Staromiejska). Fakt ten był często interpretowany jako relikt osady przedlokacyjnej o kształcie owalnicowym, ale badania terenowe nie potwierdziły dotychczas na tym terenie śladów osadnictwa wczesnośredniowiecznego ${ }^{12}$. W obrębie czworokątnego obrysu miasta $\mathrm{w}$ jego południowo-wschodnim narożniku zarezerwowano miejsce na zamek ${ }^{13}$. W źródłach piętnastowiecznych pojawiają się też wzmianki o klasztorze bullatów, odłamu franciszkanów, który miał być ufundowany w Lęborku ${ }^{14}$. Zestawienie sekwencji analizowanych dendrochronologicznie próbek drewna umożliwia stwierdzenie, że największa intensywność zagospodarowania obszaru miejskiego przypadła na lata czterdzieste XIV w.

Sytuacja Pucka była nieco odmienna, bowiem nie przeniesiono ośrodka kasztelanii wczesnośredniowiecznej w nowe miejsce, tylko przeprowadzono lokację miasta w obrębie dawnego osadnictwa ${ }^{15}$. Za uformowaniem miasta w miejscu dawnego ośrodka osadniczego przemawiał najpewniej dogodny dostęp do brzegu zatoki, bowiem w planach Zakonu było ustanowienie w Pucku siedziby administratora okręgu rybickiego. Lokacja miasta potwierdzona została aktem przywileju w dniu 16 listopada 1348 r. $^{16}$, a przeprowadzona została na obszarze regularnego

${ }^{6}$ W sumie sieć miejską stanowiło 18 mniejszych miast oraz Gdańsk, w którym do końca XIV w. lokowano trzy osady. Przed omawianą akcją lokacyjną z lat czterdziestych i pięćdziesiątych XIV w. lokowano tylko Gniew (w 1297 r.), po zajęciu ziemi gniewskiej jeszcze w XIII w. oraz Skarszewy, które założyli Joannici w 1320 r., zaś Krzyżacy wykupili i rozszerzyli przywilej w roku 1370. Istnieją przesłanki, aby uznać, że jakąś formę samorządności uzyskały w połowie drugiej dekady XIV w. Chojnice i Tczew, Biskup M. 1980; Grzegorz M. 1988; Grzegorz M. 2007, s. 120-125; Biskup M., Labuda G. 1986, s. 319-320; Czaja R. 2000, s. 51; Starski M. 2015.

7 Biskup M., Labuda G. 1986, s. 321-323; Bruski K. 1998, s. 74-77; Bruski K. 2009, s. 26-27, 51-52.

8 Bruski K. 2009, s. 37-41.

9 Lęga W. 1956, s. 174-175, 188-189; Bruski K. 2009, s. 26-27.

10 Bruski K. 2009, s. 33-34.

11 Ślaski K. 1948; Szulist W. 1970.

12 Bruski K. 2009, s. 26-34.

13 Dotychczasowe badania archeologiczne na terenie omawianego miasta doprowadziły do rozpoznania 18 parcel mieszczańskich, placu rynkowego, pasa umocnień miejskich i osady przedmiejskiej przed Bramą Słupską. Prace prowadzono głównie w północno-wschodnim bloku zabudowy przyrynkowej (badania mgr. J. Gzowskiego, dr. A. Longi, mgr. M. Marczewskiego), poza tym przy ul. M. Reja 14 (badania mgr A. Krzysiak i mgr. M. Szyszki) oraz przy ul. Kard. S. Wyszyńskiego 2-4 (badania M. Marczewskiego). Południową część placu rynkowego badał Autor, zaś centralną i północną mgr M. Ignasiak. Prace w rejonie murów miejskich realizowali mgr J. Borkowski i mgr J. Garlicki, zaś osadę przed Bramą Słupską rozpoznała mgr E. Skarbek.

14 Bruski K. 2009, s. 61-62.

15 Śliwiński B. 1998, s. 61; Starski M. 2017, s. 47.

16 Ślaski B. 1916, s. 1-5; Bruski K. 1998, s. 74-75. 
czworoboku o wielkości ok. 8 hektarów (ryc. 1B). Wokół prostokątnego rynku zlokalizowano sześć dużych i dwa mniejsze bloki zabudowy. W północnej części miasta, poza jednym blokiem zabudowy, zlokalizowany był kościół, zaś narożnik północno-zachodni pozostawiono z przeznaczeniem na siedzibę urzędnika zakonnego. Dotychczasowe badania archeologiczne wskazały na największą koncentrację śladów osadnictwa przedlokacyjnego w rejonie kościoła i na wschód od niego, jak również dalsze istnienie dawnej osady poza obszarem miasta w kierunku wschodnim ${ }^{17}$. Wykopaliska prowadzone w centralnej i południowej części miasta nie ujawniły śladów trwałego zasiedlenia tego terenu przed lokacją ${ }^{18}$. Tak jak w przypadku Lęborka, badania archeologiczne dostarczyły tu licznych danych świadczących o tym, że proces zasiedlenia i zagospodarowania postępował w latach bezpośrednio po lokacji, a pojedyncze miejsca zagospodarowano na początku czwartej ćwierci XIV w. ${ }^{19}$

Jak zatem można zauważyć obydwa omawiane miasta zostały lokowane przez Zakon jako podobnej wielkości ośrodki, a pomyślnie przeprowadzony proces lokacji usankcjonował ich status jako lokalnych centrów działalności handlowej i rzemieślniczej w kolejnych dziesięcioleciach. Stały się one także lokalnymi ośrodkami administracji zakonnej w obrębie komturstwa gdańskiego przez lokalizację wójtostwa w Lęborku i urzędu rybickiego w Pucku² .

Podstawą źródłową dla rozważań nad tytułowym tematem są znaleziska fragmentów naczyń ceramicznych pochodzące z różnych miejsc badanych w obrębie każdego z omawianych ośrodków. Na łączną liczbę ok. 40 tysięcy pozyskanych w Pucku, a datowanych na okres późnego średniowiecza, aż 12682 fragmenty pochodziły z nawarstwień powstałych między połową XIV a połową XV w., przy czym $92,9 \%$ spośród nich — z drugiej połowy XIV stulecia. W zbiorze tym wyróżniono łącznie 4658 naczyń, z których na drugą połowę XIV w. przypada 91,2\% Podstawa ta, w przeważającej większości opracowana i publikowana, wydaje się być reprezentatywna dla podjęcia charakterystyki miejscowej produkcji garncarskiej, choć nie odkryto dotychczas pozostałości warsztatów garncarskich z czasu kształtowania się miasta ${ }^{22}$.

W Lęborku podstawę źródłową stanowi zbiór ok. 13000 fragmentów naczyń, z których z najstarszej fazy istnienia miasta pochodzą 6054 sztuki, datowane od lat czterdziestych XIV po połowę XV w. Wśród nich więcej niż połowę stanowią znaleziska z XIV w. (57,5\%). Wyróżniono łącznie 2325 naczyń, z czego na drugą połowę XIV w. przypada 59,3\%. Zbiór ten, choć dwa razy mniejszy od puckiego, jest wystarczająco liczny dla nakreślenia charakterystyki miejscowej produkcji garncarskiej ${ }^{23}$. Mankamentem, podobnie jak w odniesieniu do Pucka, jest

17 Starski M. 2017a, s. 47-49.

18 Dotychczasowe wykopaliska doprowadziły do rozpoznania 33 parcel mieszczańskich, placu rynkowego, pasa umocnień miejskich oraz założenia zamkowego i terenu osadnictwa podmiejskiego, por. Blusiewicz K., Kruppé J., Milewska M., Starski M. 2014; Starski M. 2017 b.

${ }_{19}$ Kruppé J., Milewska M. 2015, s. 55; Starski M. 2017a, s. 49.

20 Tandecki J. 2000, s. 22; Czaja R. 2000, s. 51.

${ }^{21}$ Znaleziska pochodzą łącznie z 19 parcel mieszczańskich, dwóch ulic, placu rynkowego oraz z Wsi Puckiej. Z analizy wyłączono naczynia ceramiczne z zamku, bowiem ich zbiór datowany jest na schyłek pierwszej połowy XV w. i wykazuje cechy bliższe drugiej połowie XV w. Wśród 4658 naczyń wyróżniono 258 wyrobów obcych, tj. kamionkowych i ceglastych polewanych. Kwestie metodyczne związane z rekonstrukcją liczby naczyń omówiono w odrębnym opracowaniu, Starski M. 2016a, s. 43-52, tab. 3.

${ }^{22}$ Większość znalezisk została opublikowana w pracy poświęconej miejscowej wytwórczości garncarskiej (Starski M. 2016a). W podstawie źródłowej uwzględniono jeszcze trzy działki miejskie badane już po roku 2016.

${ }^{23}$ Dotychczas opublikowano zbiór znalezisk pochodzący z 13 parcel położonych w północno-wschodnim bloku zabudowy przyrynkowej (Starski M. 2016b, tam też omówiono kwestie metodyczne związane z rekonstrukcją liczby naczyń). Niepublikowane opracowania poświęcono znaleziskom z południowej części placu rynkowego (Golonka T. 2017), ul. Reja 14 i ul. kard. S. Wyszyńskiego 2-4 (opracowania Autora). W zbiorze 2325 naczyń wyróżniono 52 wyroby obce, tj. kamionkowe i ceglaste polewane. 
Tabela 1

Zestawienie liczebności i udziału procentowego naczyń ceramicznych z Pucka i Lęborka według gatunków

Table 1

Summary of the number and percentage of ceramic vessels from Puck and Lębork by types

\begin{tabular}{|c|c|c|c|c|c|c|}
\hline \multirow{3}{*}{ Miasto } & \multicolumn{6}{|c|}{ Naczynia ceramiczne } \\
\hline & \multirow{2}{*}{ Datowanie } & \multirow{2}{*}{$\begin{array}{c}\text { Liczebność i udzial } \\
\text { procentowy }\end{array}$} & \multicolumn{3}{|c|}{ Gatunki } & \multirow{2}{*}{ Lącznie } \\
\hline & & & tradycyjne & siwaki & ceglaste & \\
\hline \multirow[t]{6}{*}{ Puck } & \multirow[t]{2}{*}{ druga połowa XIV w. } & liczba & 1391 & 2518 & 124 & 4033 \\
\hline & & $\%$ & 34,5 & 62,4 & 3,1 & 100,0 \\
\hline & \multirow{2}{*}{ pierwsza połowa XV w. } & liczba & 73 & 273 & 21 & 367 \\
\hline & & $\%$ & 19,9 & 74,4 & 5,7 & 100,0 \\
\hline & \multirow[t]{2}{*}{ lącznie } & liczba & 1464 & 2791 & 145 & 4400 \\
\hline & & $\%$ & 33,3 & 63,4 & 3,3 & 100,0 \\
\hline \multirow{6}{*}{ Lębork } & \multirow{2}{*}{$\begin{array}{l}\text { lata czterdzieste- } \\
\text {-koniec XIV w. }\end{array}$} & liczba & 14 & 1316 & 17 & 1347 \\
\hline & & $\%$ & 1,0 & 97,7 & 1,3 & 100,0 \\
\hline & \multirow[t]{2}{*}{ pierwsza połowa XV w. } & liczba & 0 & 884 & 42 & 926 \\
\hline & & $\%$ & 0,0 & 95,5 & 4,5 & 100,0 \\
\hline & \multirow[t]{2}{*}{ fącznie } & liczba & 14 & 2200 & 59 & 2273 \\
\hline & & $\%$ & 0,6 & 96,8 & 2,6 & 100,0 \\
\hline
\end{tabular}

brak odkrytych warsztatów garncarskich z połowy lub drugiej połowy XIV stulecia, a także znalezisk z niemal całej południowo-zachodniej części miasta.

W najstarszym okresie funkcjonowania miasta lokacyjnego w Pucku, czyli od ok. połowy do końca XIV w., wśród naczyń ceramicznych wytwarzanych na miejscu stwierdzono trzy gatunki wyrobów: tradycyjne, siwaki i ceglaste ${ }^{24}$ (tab. 1). Naczynia tradycyjne stanowią grupę o znacznym zróżnicowaniu technologicznym i morfologicznym (ryc. 2). Ich cechą wspólną jest kontynuacja tradycji wytwórczości schyłkowo wczesnośredniowiecznej obserwowanej w ceramice pomorskiej ${ }^{25}$. Dotyczy to przede wszystkim atmosfery wypalania, która była zbliżona do warunków redukcyjnych; w jej efekcie powierzchnia zyskała barwę brunatną lub beżową ${ }^{26}$. Masa ceramiczna użyta do wyrobu tych naczyń to thusta glina ze średnią lub dużą ilością sztucznie dodanej domieszki schudzającej, w postaci tłucznia kamiennego o różnej ziarnistości ${ }^{27}$. Ornamentyka wyrobów nawiązywała do stylistyki wczesnośredniowiecznej, tj. dookolnych linii rytych, najczęściej prostych, ale także falistych. Naczynia te były w większości płaskodennymi garnkami (ok. 96\% w drugiej połowie XIV w. ${ }^{28}$ ), a wyróżniono tylko pojedyncze misy, pokrywki i dzbany (ryc. 2: 1-3, 9-11,13). W obrębie omawianego gatunku ok. 20\% to wyroby pochodzące tylko z najstarszych nawarstwień, przejawiające wyłącznie cechy wytwórczości schyłkowo wczesnośredniowiecznej ${ }^{29}$. Pozostała, zdecydowana większość nosiła cechy nawiązujące do wyrobów wytwarzanych przez ludność napływową w Pucku, wywodzącą się z krajów niemieckich lub wcześniej zaznajomioną z charakterystyczną dla niej w tym czasie produkcją przy zastosowaniu wypalania w atmosferze redukcyjnej. Wyróżnikami tych egzemplarzy przede

${ }^{24} \mathrm{Z}$ analizy wyłączono pojedyncze fragmenty naczyń kamionkowych i ceglastych polewanych. Odnośnie do definicji wyróżnionych grup, por. Starski M. 2016a, s. 40-41.

${ }_{25}$ Auch M. 2001; Kruppé J., Milewska M. 2015, s. 18-21.

26 Starski M. 2016a, s. 104-107, 131-133.

27 Starski M. 2016a, s. 107-118.

${ }^{28}$ Starski M. 2016a, tab. 14, s. 140-141.

${ }^{29}$ Przypuszczalnie to naczynia, które trafiały na rynek miejski spoza Pucka, jako efekt wymiany handlowej z osadami wiejskimi położonymi w okolicy, których mieszkańcy uczestniczyli w targach. 


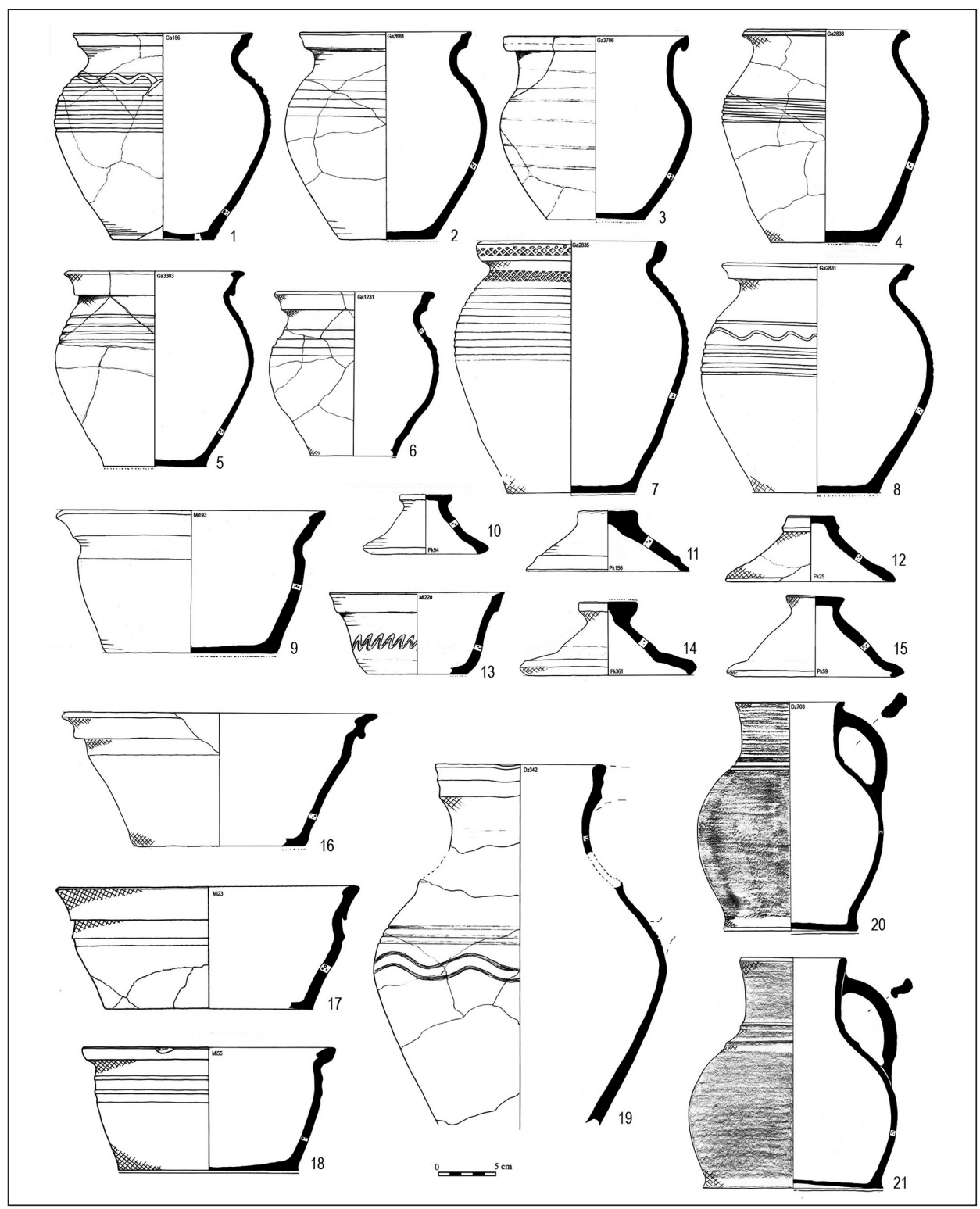

Ryc. 2. Asortyment naczyń tradycyjnych $(1-3,9-11,13)$ i siwaków $(4-8,12,14-21)$ używanych w Pucku w drugiej połowie XIV i w pierwszej połowie XV w. (rys. M. Starski)

Fig. 2. Assortment of traditional $(1-3,9-11,13)$ and grey wares $(4-8,12,14-21)$ used in Puck in the second half of the 14th and first half of the 15th c. (drawing by M. Starski)

wszystkim był kształt — nieco smuklejszy niż pomorskich naczyń wczesnośredniowiecznych (czyli baniastych garnków o maksymalnej wydętości brzuśca umieszczonej nieco ponad połową wysokości) oraz o średnicach den porównywalnych ze średnicami wylewów. Garnki te często miały wylewy z wrębem i okapem, niespotykane wcześniej w produkcji miejscowej (ryc. 3). 


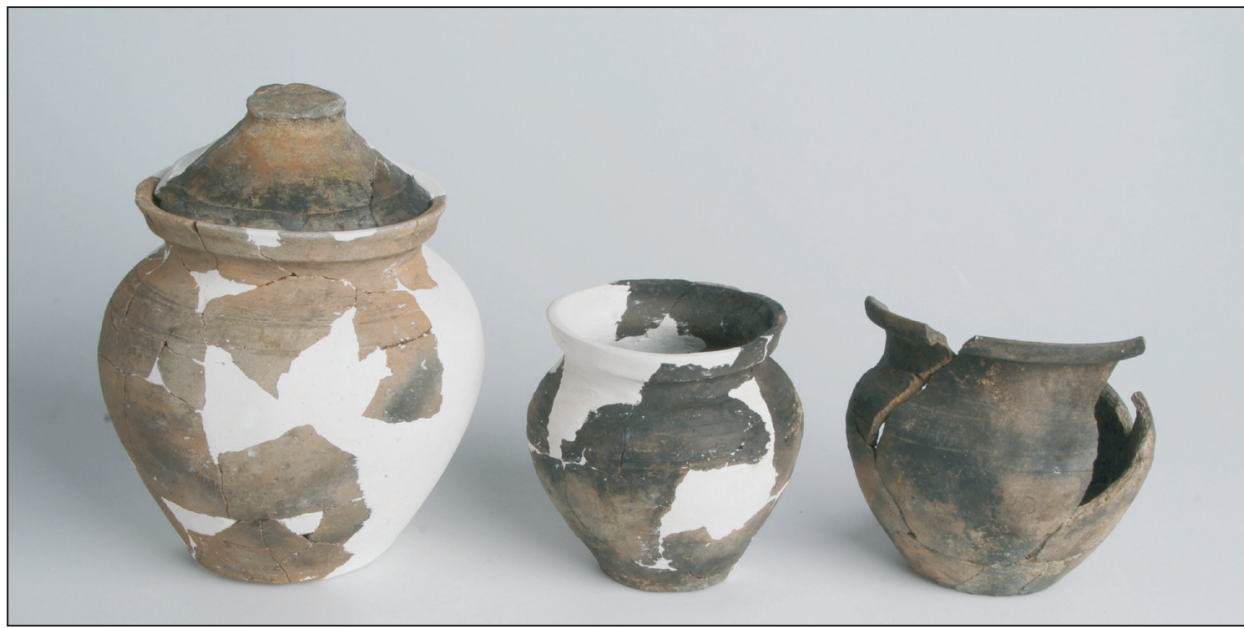

Ryc. 3. Wybór naczyń tradycyjnych z Pucka z drugiej połowy XIV w. (fot. M. Starski)

Fig. 3. Selected traditional wares from Puck from the second half of the 14th c. (photo by M. Starski)

W przełomach ścianek tych naczyń zaobserwowano lepiej wysortowaną domieszkę thucznia lub chudszą masę ceramiczną użytą do produkcji. Pojedyncze naczynia, mimo użycia tłucznia, zostały wypalone w regularnej atmosferze redukcyjnej.

Naczynia opisanego powyżej gatunku, ze względu na ich cechy morfologiczne i technologiczne, zostały uznane za produkty wytwórczości lokalnych garncarzy ${ }^{30}$, działających w mieście lub w najbliższej okolicy, którzy do swojego warsztatu wprowadzali nowości obserwowane u garncarzy napływowych. Podobne interpretacje sugerowano już wcześniej w odniesieniu do wyrobów z innych ośrodków miejskich formowanych w XIII-XIV w., np. z Gdańska ${ }^{31}$, Elbląga ${ }^{32}$, Kołobrzegu $^{33}$, Szczecina ${ }^{34}$, Kruszwicy ${ }^{35}$ i Wrocławia ${ }^{36}$.

Wytwarzane przez kolonistów naczynia pojawiły się w mieście już od momentu zasiedlenia poszczególnych posesji. Były to powszechne w późnym średniowieczu egzemplarze zawdzięczające swą ciemnoszarą lub stalową barwę wypalaniu w atmosferze redukcyjnej. Wykonywano je z chudszej gliny, ze sztucznie dodaną domieszką schudzającą drobno- i średnioziarnistego piasku. W asortymencie dominowały garnki $(71,5 \%)$, ale znaczny był też udział dzbanów $(18,6 \%)$, mis $(3,9 \%)$ i pokrywek $(5,5 \%)$, a stwierdzono także pojedyncze kubki i naczynia inne (ryc. 2: 4-8, 12, 14-21). Garnki były stosunkowo jednorodne pod względem kształtu: płaskodenne, ze średnicą dna zbliżoną do średnicy wylewu, o kształcie baniastym, z maksymalną wydętością brzuśca umieszczoną powyżej połowy wysokości (ryc. 2, 4). Ok. 57\% tego rodzaju wyrobów miało wylewy z okapem i wrębem na pokrywkę, zaś pozostałe tylko wrąb, albo też były wywinięte na zewnątrz. Ornamentowano je z reguły prostymi dookolnymi liniami rytymi. Na powierzchni ok. kilkunastu procent odciśnięto wzór radełka. Misy to wyroby szerokootworowe, niskie, o wylewach masywnych, wywiniętych lub z okapem i wrębem na pokrywkę. Dzbany miały maksymalną wydętość brzuśca osadzoną w dolnej części

${ }^{30}$ Problem ten w skali ogólnej opisał wcześniej J. Kruppé 1981, s. 60-119.

31 Kruppé J. 1981, s. 100-110.

${ }^{32}$ Nawrolscy G., T. 1986, s. 635-637; Marcinkowski M. 2006, s. 273-275; Nawrolska G. 2012, s. 54-56.

33 Rębkowski M. 1995, s. 73-86.

34 Łosiński W., Rogosz R. 1986.

35 Dzieduszycki W. 1982, s. 108-110.

36 Rzeźnik P. 1998. 


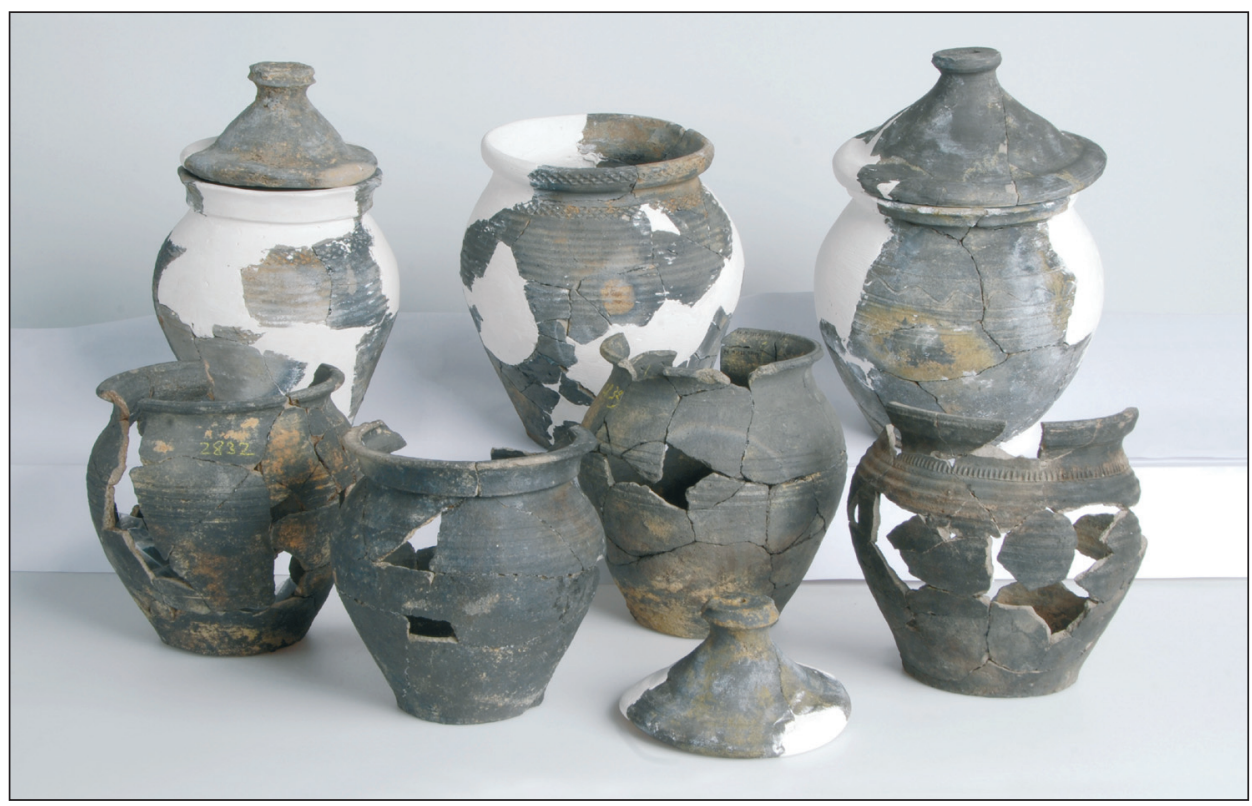

Ryc. 4. Wybór siwaków z Pucka z drugiej połowy XIV w. (fot. M. Starski)

Fig. 4. Selected grey wares from Puck from the second half of the 14th c. (photo by M. Starski)

naczynia, długą smukłą szyjkę oraz esowate bądź lekko rozchylone wylewy. Ornamentowano je liniami dookolnymi lub radełkiem, choć dominowało polerowanie powierzchni. Pokrywki były kształtu cylindrycznego z masywnymi guzkami (ryc. 2, 4).

Naczynia ceglaste w znikomej liczbie (tylko 145 sztuk) nawiązywały techniką i formą wykonania oraz stylistyką zdobienia do siwaków, co uprawnia do przypuszczania, że być może stanowiły niezamierzony efekt produkcji naczyń wypalanych w atmosferze redukcyjnej, które ze względu na dobre cechy użytkowe zostały przeznaczone na sprzedaż na rynku wewnętrznym miasta ${ }^{37}$.

Zarysowane zróżnicowanie wyrobów ceramicznych używanych w najstarszym okresie dziejów lokacyjnego Pucka wskazuje zatem na istnienie dwóch odrębnych tradycji produkcyjnych, które współegzystowały ze sobą w pierwszych dziesięcioleciach po lokacji miasta. Jedna z nich interpretowana jest jako próba adaptacji tradycyjnego warsztatu do wyzwań rynkowych kształtującego się miasta i jego społeczności przez oferowanie nowym odbiorcom wyrobów odpowiadających ich potrzebom. Stąd przyjmowanie nowych elementów w wytwórczości schyłkowo wczesnośredniowiecznej, co w literaturze przedmiotu określane jest jako warsztat tradycyjny. Drugi nurt w produkcji, który od początku dominował w strukturze wytwarzanych w lokacyjnym Pucku wyrobów, to siwaki oferowane mieszkańcom przez napływowych garncarzy. Niewykluczone, że zarówno producenci, jak i odbiorcy mogli pochodzić z tego samego regionu i znali preferencje w zakresie wyposażenia gospodarstw domowych w naczynia oraz uwarunkowania produkcji. Zadecydowało to o rytmie przemian, których efektem była w tamtejszej produkcji dominacja siwaków.

37 Pozostałe gatunki naczyń ceramicznych z Pucka stanowiły margines asortymentu wyrobów używanych w drugiej połowie XIV w. Wyróżniono wśród nich pojedyncze naczynia ceglaste polewane $(1,8 \%)$ i kamionkowe $(3,1 \%)$, które są świadectwem sprowadzania do miasta wyrobów obcych. Ważnym aspektem w odniesieniu do miejscowej wytwórczości jest fakt, że ich udział (nie przekraczający łącznie 5\%) nie stanowił w czasie kształtowania się Pucka zagrożenia dla rozwoju lokalnej produkcji ceramicznej. 
Powyższa rekonstrukcja najpewniej nie jest jedyną możliwą hipotezą odnośnie do kształtowania się puckiego garncarstwa w XIV w. Nie wiadomo bowiem chociażby, jak liczni byli rzemieślniczy działający w obrębie obydwu nurtów, oraz czy garncarze rodzimi funkcjonowali w mieście, czy też poza nim. Są to zmienne mogące zasadniczo wpłynąć na obraz zmian w produkcji ceramicznej w drugiej połowie XIV stulecia. W odniesieniu do tych dwóch kwestii można jedynie przypuszczać, że najpewniej każdy z omawianych gatunków naczyń był wytwarzany przez więcej niż jednego garncarza. Ich zróżnicowanie jest bowiem na tyle znaczące, że widoczne są w nim różne tradycje warsztatowe. Jednocześnie, skoro wyroby tradycyjne stanowiły prawie jedną trzecią używanych naczyń, sporo przemawia za ich produkcją w obrębie miasta. Nie wiadomo jednak jak wówczas interpretować nakreśloną wcześniej koegzystencję garncarzy. Pewnego wyjaśnienia dostarczają znaleziska datowane na koniec XIV w. oraz na pierwszą połowę XV w. Odnotować można bowiem stopniowe zmniejszanie się, a wreszcie zanik naczyń tradycyjnych, oraz ujednolicenie produkcji przez zdominowanie jej przez siwaki (tab. 1). Oznacza to, że w ciągu pół stulecia prawie zaprzestano produkowania naczyń tradycyjnych. Możliwe, że wiązało się to z przejęciem większości cech wytwórczości kolonizacyjnej przez garncarzy rodzimych, czyli właściwie ich dostosowanie się do potrzeb rynku, tj. większego popytu na siwaki. Z drugiej strony istnieje ewentualność, że stosowanie technik tradycyjnych wiązało się ze zmianami pokoleniowymi w garncarstwie puckim. Należałoby wówczas przyjąć, że okres jednego do dwóch pokoleń wystarczył do przestawienia całości produkcji na wyrób naczyń wypalanych w atmosferze redukcyjnej. Omawiane zmiany trzeba by zatem postrzegać nie jako ewolucję tylko zaprzestanie wytwarzania naczyń tradycyjnych, będące efektem odejścia pokolenia garncarzy produkujących naczynia w znanej im starej technice i stylistyce.

$\mathrm{Na}$ tym tle odmienna sytuacja dotyczy rzemiosła garncarskiego w Lęborku. Od początku istnienia miasta można odnotować zdominowanie asortymentu produkcji przez siwaki, które w nawarstwieniach z lat czterdziestych i z drugiej połowy XIV w. stanowiły ponad $97 \%$ znalezisk. Wyroby te cechowało duże podobieństwo do naczyń puckich pod względem kształtu i użytego surowca; wyrabiano je z chudych glin żelazistych ze sztucznie dodaną domieszką drobno- i średnioziarnistego piasku. W porównaniu z egzemplarzami puckimi są one lepiej wypalone (tzw. dźwięczące, mniej pyliste w fakturze i bardziej cienkościenne), ale mają liczniejsze, nie do końca zagładzone ślady poprodukcyjne (w postaci widocznych miejsc sklejenia taśm). Dominują wśród nich płaskodenne garnki z maksymalną wydętością brzuśca umieszczoną powyżej połowy wysokości naczynia (64,3\%). Udział wylewów z okapem i wrębem na pokrywkę jest nieco niższy niż w Pucku, ale zbliżony (ok. 45\%). Liczne są dzbany (18,4\%), misy (9,3\%) i pokrywki (7,2\%) (ryc. 5: 2-16; 6). Powszechniej niż w Pucku stosowano dekorację wykonaną przy użyciu radełka ${ }^{38}$.

Pojedyncze wyroby ceglaste to najpewniej nieudane efekty wypalania redukcyjnego, które mimo to trafiły na sprzedaż ${ }^{39}$. Tylko $0,6 \%$ stanowią natomiast naczynia tradycyjne i poza jednym całym egzemplarzem (ryc. 5:1) to wyroby zachowane fragmentarycznie. Najprawdopodobniej wskazuje to zatem na brak wytwórczości schyłkowo wczesnośredniowiecznej współistniejącej z wytwórczością osadników przybyłych, zarówno w mieście, jak i w jego najbliższym otoczeniu. Bez wątpienia wyróżnione wśród znalezisk nieliczne naczynia tradycyjne trafiły do Lęborka spoza najbliższej okolicy, zapewne jako opakowania produktów lub jako wyroby sprzedane na miejskim targu.

Taka struktura wyrobów garncarskich wskazuje, że garncarstwo lęborskie kształtowało się zupełnie inaczej niż puckie - w całości oparte było na produkcji naczyń wypalanych w atmosferze redukcyjnej. Najpewniej nawet w sąsiedztwie miasta nie funkcjonowały warsztaty wy-

38 Starski M. 2016b, s. 239-242.

39 Pozostałe gatunki ceramiki stanowią tylko 4,7\%, przy czym połowa z nich to sprowadzane do Lęborka naczynia kamionkowe i ceglaste polewane, Starski M. 2016b, s. 239-242; Starski M. 2016c, s. 155-161. 

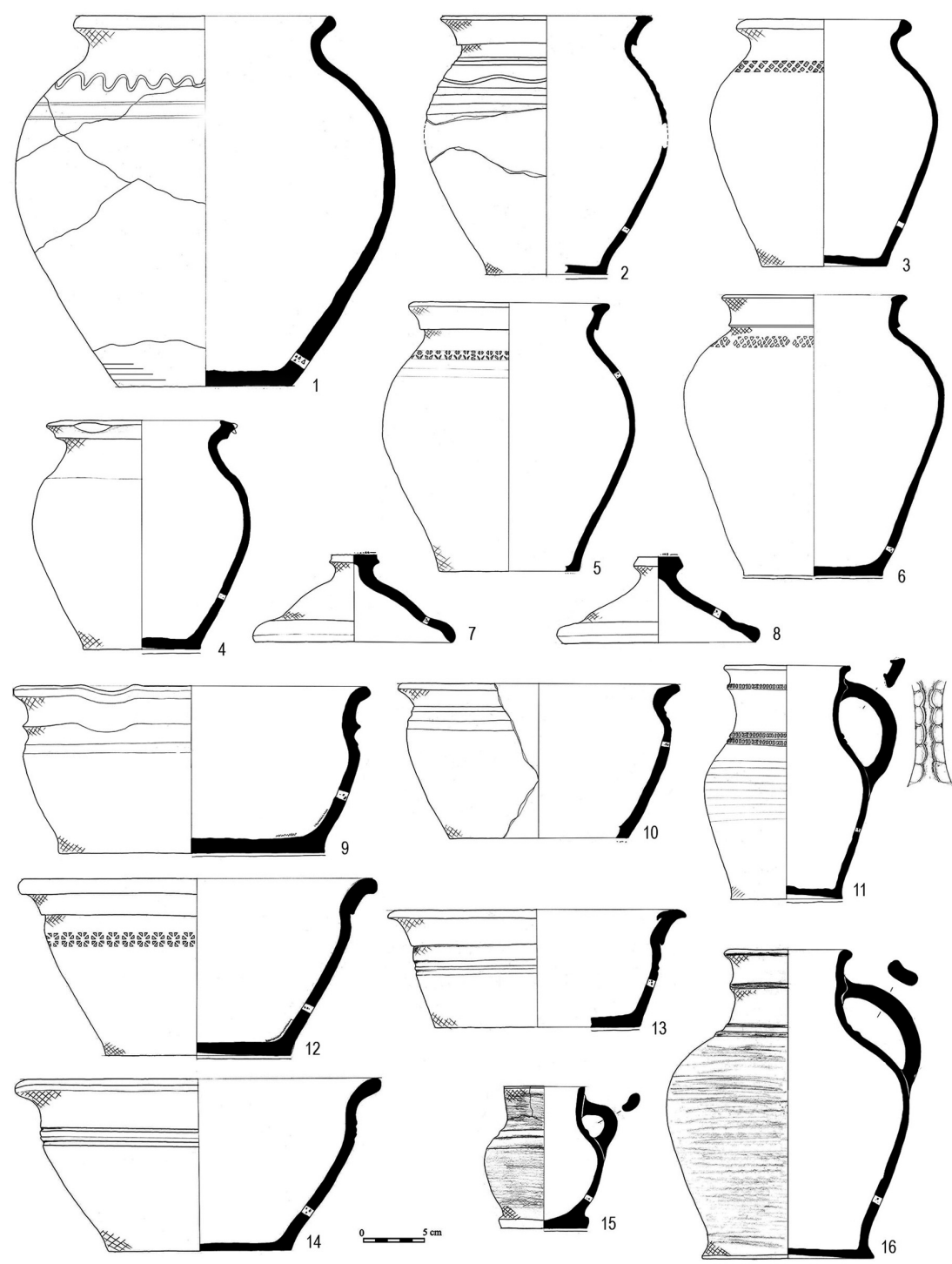

Ryc. 5. Asortyment naczyń tradycyjnych (1) i siwaków (2-16) używanych w Lęborku w drugiej połowie XIV i w pierwszej połowie XV w. (rys. M. Starski)

Fig. 5. Assortment of traditional (1) and grey wares (2-16) used in Lębork in the second half of the 14th and first half of the 15th c. (drawing by M. Starski)

twarzające naczynia tradycyjne, zaś w pobliskich wsiach prawdopodobnie również działali garncarze napływowi ${ }^{40}$. Sytuacja taka wpłynęła na długie trwanie modelu miejscowego garncarstwa opartego niemal w całości na produkcji naczyń wypalanych w atmosferze redukcyjnej.

${ }^{40}$ Na napływowe pochodzenie mieszkańców Nowej Wsi Lęborskiej wskazywano już wcześniej, Bruski K. 2009, s. 30-33. 


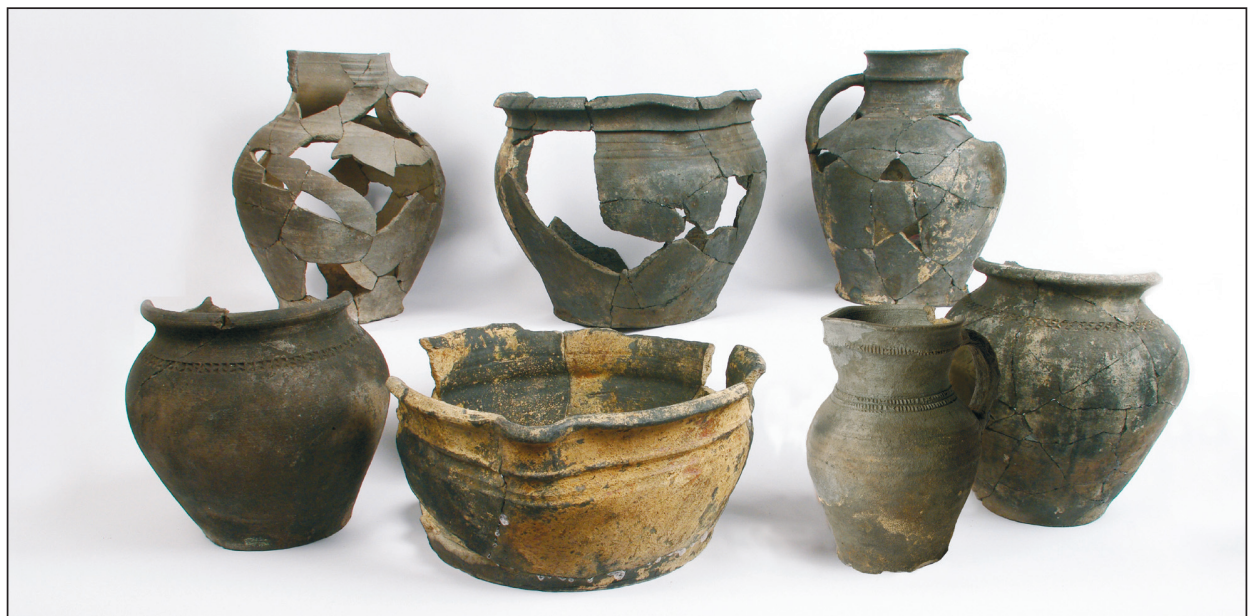

Ryc. 6. Wybór siwaków z Lęborka z drugiej połowy XIV w. (fot. I. Nazaruk)

Fig. 6. Selected grey wares from Lębork from the second half of the 14th c. (photo by I. Nazaruk)

Jest to widoczne w strukturze wyrobów używanych w pierwszej połowie XV w., w której zróżnicowanie gatunków jest bardzo podobne. Zmiany rysują się jedynie w zakresie ukształtowania wylewów i ornamentyki wyrobów; nieco rzadsze są naczynia zdobione radełkiem, mniej jest garnków z okapem i wrębem na pokrywkę, więcej zaś naczyń z wylewem wywiniętym na zewnątrz bez wrębu. Podobnie jak w przypadku Pucka, nie można ustalić liczby warsztatów działających w Lęborku i w jego okolicy. Można jednak założyć, że na potrzeby miasta musiało pracować kilku garncarzy i to zapewne już od momentu jego założenia.

Nakreślone wyżej dwa różne warianty kształtowania się garncarstwa w dwóch małych miastach Pomorza Gdańskiego dostarczają istotnych, choć nierozstrzygających informacji dotyczących procesu kształtowania się omawianych ośrodków. Stanowią również punkt wyjścia dla podjęcia tematu, na ile są to sytuacje jednostkowe, na ile zaś mają szersze znaczenie dla charakterystyki kształtowania się innych ośrodków miejskich.

Na podstawie charakterystyki opisywanych nurtów w produkcji ceramicznej można sądzić, że w fazie kształtowania się miasta lokacyjnego w Pucku jego społeczność, oprócz ludności napływowej, tworzyła też pewna grupa ludności miejscowego pochodzenia. Do takiego poglądu uprawnia nie tyle prawdopodobieństwo funkcjonowania w Pucku warsztatu lub warsztatów garncarskich, w których wyrabiano naczynia nawiązujące do tradycji wczesnośredniowiecznej, ale w większym stopniu wskazuje na to ponad $30 \%$ udział tych wyrobów w strukturze naczyń używanych w mieście w drugiej połowie XIV w. Oznacza to bowiem, że istniało tam zapotrzebowanie na określone wyroby i pewna stała grupa odbiorców i to raczej nie napływowych. $\mathrm{Z}$ drugiej strony nie można wykluczyć, że w początkowej fazie funkcjonowania ośrodka istniał niedobór naczyń wypalanych w atmosferze redukcyjnej. Ich brak ludność napływowa kompensowała nabywaniem naczyń tradycyjnych. Wydaje się jednak, że sytuacja taka byłaby raczej krótkotrwała, zaś udział takich wyrobów jest zbyt znaczący i trwający zbyt długo, by tylko w ten sposób wyjaśnić kontynuowanie produkcji naczyń tradycyjnych. Naczynia te dominują w asortymencie wyrobów używanych we Wsi Puckiej, położonej obok miasta ${ }^{41}$.

\footnotetext{
41 Starski M. 2016a, s. 198.
} 
Powyższe kwestie nie mogą być rozważane wyłącznie na podstawie struktury użytkowania naczyń ceramicznych, choć wnioski te prezentują się obiecująco. Istotne są także wiadomości ze źródeł pisanych, wskazujące na pochodzenie ludności miejskiej. W przypadku Pucka dysponujemy pewnym zasobem informacji, tj. listą 448 nazwisk mieszczan, zawartą w księdze miejskiej prowadzonej od końca XIV do lat siedemdziesiątych XV w. ${ }^{42}$ Ich analiza wskazuje na źródłosłów od wykonywanych zajęć, miast i regionów, sugerując ich pochodzenie z Brandenburgii, Meklemburgii, Turyngii, Westfalii oraz Prus i Pomorza Zachodniego ${ }^{43}$. Część nazwisk ma brzmienie słowiańskie, zniemczone w zapisie źródłowym. Fakt ten zdaje się potwierdzać, że w jakimś, choć nieznanym stopniu, strukturę kształtującego się miasta tworzyli również miejscowi. Chociaż w tym konkretnym przypadku przekazy archiwalne zdają się umniejszać ich rolę w kształtowaniu się społeczności ośrodka, to archeologiczne przemawiają za większym udziałem tej grupy. Wydaje się zatem, że kwestia ta nie jest zamknięta. Przydatna byłaby także analiza innych niż garncarstwo dziedzin kultury materialnej, aby również tam odnaleźć te elementy, które wskazują na miejscowe pochodzenie części mieszkańców miasta.

Analiza struktury wyrobów garncarskich z Lęborka uprawnia do zgoła odmiennej interpretacji i przemawia za podnoszoną w literaturze przedmiotu hipotezą o lokacji miasta na surowym korzeniu ${ }^{44}$. Świadczy o tym niemal całkowity brak innych gatunków naczyń wytwarzanych na miejscu niż wypalane w atmosferze redukcyjnej. Tak jednorodny charakter produkcji wskazuje na zupełnie inne warunki kształtowania się podaży i popytu na wyroby garncarskie. Najprawdopodobniej cała produkcja była tam zdominowana przez garncarzy napływowych. Jednocześnie niemal zupełny brak naczyń tradycyjnych wskazuje na znikome oddziaływanie garncarzy pochodzących z okolicy miasta. Najpewniej świadczy też o niewielkim, jeśli w ogóle, udziale ludności miejscowej w strukturze społeczności średniowiecznego Lęborka. Grupa ta, obecna wśród mieszkańców, musiałaby pozostawić jakiś ślad w asortymencie używanych wyrobów ceramicznych, chociażby przez szersze kontakty z otoczeniem. W tym przypadku niewielkim wsparciem są źródła pisane, które wzmiankują tylko kilkunastu ówczesnych mieszczan. Ich nazwiska są niemieckie, z czego dwa wskazują na pochodzenie westfalskie i turyńskie, a tylko jedno ma pierwotną formę słowiańską ${ }^{45}$.

Powyższe rozważania zdają się potwierdzać przypuszczenia formułowane na podstawie analizy skromnych przekazów źródłowych — że w przypadku Pucka w zasiedleniu miasta brała udział pewna grupa ludności miejscowej, zaś w Lęborku zaludnianie mogło odbywać się niemal wyłącznie przy udziale obcych osadników. Równocześnie może to świadczyć, iż do analizy procesów związanych z kształtowaniem się miasta mogą zostać użyte liczne i reprezentatywne źródła materialne w postaci naczyń ceramicznych.

Wiele też wskazuje, że w nakreślonych wariantach kształtowania się garncarstwa w Pucku i Lęborku można dostrzegać procesy o znaczeniu szerszym, a nawet modelowym, przy czym nie jest to spostrzeżenie jednakie dla wszystkich ośrodków miejskich. O wiarygodności interpretacji świadczy bowiem określona liczba zmiennych dotyczących procesu kształtowania się tych miast. Wydaje się, że w przypadku mniejszych ośrodków wnioski takie są uprawnione, o ile rozporządzamy odpowiednią podstawą źródłową. Ustalenia te mogą być niejednoznaczne w stosunku do miast większych oraz rozwijających się w innych warunkach polityczno-ekonomicznych. Wymagałyby one przede wszystkim udokumentowania konkretnymi przykładami, ale wówczas możliwe byłoby uzyskanie jeszcze innego obrazu rozwoju rzemiosła garncarskiego.

42 Penners T. 1942, s. 134-135; Schulz F. 2011, s. 129-136.

43 Dla 36 nazwisk notowanych w latach 1398-1425 T. Penners ustalił, że 25\% spośród nich pochodziło z Turyngii, Hesji i Saksonii, 13,8\% z Meklemburgii, Brandenburgii i Pomorza Zachodniego, 22,2\% z Prus właściwych i Pomorza Gdańskiego oraz 5,5\% z Królestwa Polskiego. Dla pozostałych 33,5\% miejsc pochodzenia nie ustalono, przy czym wg Autora badań przybyli oni z państw niemieckich lub terytorium objętych kolonizacją niemiecką, a więc także Śląska, Pomorza Zachodniego i Prus właściwych, Penners T. 1942, s. 134-135.

${ }_{44}$ Bruski K. 2009, s. 26-27.

45 Bruski K. 2009, s. 51-52. 
Na tym tle warto też prześledzić, na ile odnotowane w Pucku i Lęborku przypadki kształtowania się garncarstwa można odnieść do innych miast regionu. Obecnie głównym problemem uniemożliwiającym takie porównanie jest zbyt mała liczebnie podstawa źródłowa dla pozostałych małych miast Pomorza Gdańskiego ${ }^{46}$. Dotychczasowe, bardzo wstępne dane przemawiają jednak za większą liczbą przypadków podobnych do wariantu lęborskiego. Niemal całkowity brak naczyń tradycyjnych odnotowano bowiem w Człuchowie, Debrznie i Skarszewach ${ }^{47}$. Trudniej jest określić sytuację w miastach o strukturze podobnej jak w Pucku lub o zmianach przebiegających w sposób zbliżony. Pewne wskazówki dotyczą Chojnic ${ }^{48}$ i Gniewu ${ }^{49}$, w których zarejestrowano niewielki udział znalezisk naczyń tradycyjnych. Prowadzone tam badania nie dostarczyły na tyle licznych zbiorów pochodzących z najstarszych faz istnienia miasta, aby sprawę tę rozstrzygać jednoznacznie. Ciągle też brak wystarczających zbiorów z Nowego, Starogardu Gdańskiego, Świecia i Tczewa. Pozostaje zatem tylko obiecująca perspektywa, że ewentualnie pozyskane wyroby garncarskie będą stanowić pomocne źródło informacji dla rekonstrukcji przynajmniej części procesów związanych z kształtowaniem się tych miast.

Adres Autora

dr Michał Starski

Instytut Archeologii UW

ul. Krakowskie Przedmieście 26/28

00-007 Warszawa

m.starski@uw.edu.pl

http://orcid.org/0000-0001-7995-8788

\section{BIBLIOGRAFIA}

Auch Michał. 2001. „Stan badań nad garncarstwem wczesnośredniowiecznym na Pomorzu Gdańskim”, Warszawa (maszynopis pracy magisterskiej w archiwum Zakładu Późnego Średniowiecza i Czasów Nowożytnych Instytutu Archeologii UW).

Biskup Marian. 1980. Rozwój sieci miast pruskich do drugiej połowy XVII w., „Kwartalnik Historii Kultury Materialnej”, R. XXVIII, nr 3, s. 401-412.

Biskup Marian, Labuda Gerard. 1986. Dzieje Zakonu krzyżackiego w Prusach, Gdańsk.

Blusiewicz Karolina, Kruppé Jerzy, Milewska Martyna, Starski Michał. 2014. 20 lat archeologii w mieście i na zamku puckim, [w:] Z dziejów badań archeologicznych na Pomorzu Wschodnim, red. M. Fudziński, H. Paner, Gdańsk, s. 187-200.

Bruski Klemens. 1998. Puck w czasach krzyżackich (1306-1466), [w:] Historia Pucka, red. A. Groth, Gdańsk, s. 68-90.

Bruski Klemens. 2009. Lębork w czasach średniowiecza, [w:] Dzieje Lęborka, red. J. Borzyszkowski, Lębork-Gdańsk, s. 19-98.

Choińska Elżbieta. 1971. Osadnictwo wczesno- i późnośredniowieczne w Świeciu nad Wisła w świetle badań w latach 1959-1960, „Pomorania Antiqua”, t. 3, s. 385-474.

Czaja Roman. 2000. Miasta i ich posiadtości ziemskie w państwie zakonu krzyżackiego w Prusach, [w:] Państwo zakonu krzyżackiego w Prusach. Podziaty administracyjne i kościelne w XIII-XVI wieku, red. Z. Nowak, R. Czaja, Toruń, s. 45-66.

Dzieduszycki Wojciech. 1982. Wczesnomiejska ceramika kruszwicka w okresie od 2 połowy X w. po połowe XIV w., Wrocław-Lódź.

Gaimster David. 1999. Der Keramikmarkt im Ostseeraum 1200 bis 1600: Exportkeramik als Indikator für Fernhandelsbeziehungen und die Wanderung des hansischen Handwerks und der Wohnkultur, [w:] Lübecker Kolloquium zur Stadtarchäologie im Hanseraum II: Der Handel, red. M. Gläser, Lübeck, s. 99-111.

${ }^{46}$ Starski M. 2015, s. 200-201.

${ }^{47}$ Badania Autora i mgr. M. Kurdwanowskiego, informacje pochodzą z niepublikowanych opracowań Autora.

${ }^{48}$ M.in. Walenta K., Trzcińska K., Trzciński M. 2000; Walenta K. 2002; Trzciński Ł. 2011.

${ }^{49}$ Choińska-Bochdan E. 1971. 
Golonka Tomasz. 2017. „Późnośredniowieczne naczynia ceramiczne z południowej części rynku w Lęborku", Warszawa (maszynopis pracy licencjackiej w archiwum Zakładu Archeologii Późnego Średniowiecza i Czasów Nowożytnych IA UW).

Grzegorz Maksymilian. 1988. Lokacja miast na Pomorzu Gdańskim w latach 1309-1454 na tle działalności politycznej i gospodarczej oraz administracyjnej zakonu krzyżackiego, [w:] W kręgu stanowych i kulturowych przeobrażeń Europy Pótnocnej w XIV-XVIII w., red. Z.H. Nowak, Toruń, s. 39-55.

Grzegorz Maksymilian. 2007. Pomorze Gdańskie pod rządami Zakonu krzyżackiego w latach 1308-1466, wydanie II, Bydgoszcz.

Jasiński Kazimierz. 1978. Utrata Gdańska przez państwo polskie, [w:] Historia Gdańska, t. I: (do roku 1454), red. E. Cieślak, Gdańsk, s. 322-330.

Kruppé Jerzy. 1967. Garncarstwo warszawskie w wiekach XIV i XV, Wrocław.

Kruppé Jerzy. 1981. Garncarstwo późnośredniowieczne w Polsce, Wrocław.

Kruppé Jerzy, Milewska Martyna. 2015. Puck. Archeologia o narodzinach miasta, Warszawa.

Lalik Tadeusz. 1965. Miasta Pomorza Gdańskiego i ich ustrój w XIII wieku (Uwagi polemiczno-krytyczne), „Zapiski Historyczne”, t. 30, z. 4, s. 7-35.

Łęga Władysław. 1956. Społeczeństwo i państwo gdańskopomorskie w XII i XIII wieku, Poznań.

Łosiński Władysław, Rogosz Ryszard. 1986. Próba periodyzacji ceramiki wczesnośredniowiecznej ze Szczecina, [w:] Problemy chronologii ceramiki wczesnośredniowiecznej na Pomorzu Zachodnim, red. J. Gromnicki, Szczecin, s. 51-61.

Marcinkowski Mirosław. 2006. Wytwórczość garncarska w Elblagu (na podstawie wybranego zbioru). Część 1 -średniowiecze (1237-przełom XV i XVI wieku), „Pomorania Antiqua”, t. XXI, s. 271-342.

Nawrolscy Grażyna, Tadeusz. 1986. Badania Starego Miasta w Elblagu w latach 1983-1984, „Kwartalnik Historii Kultury Materialnej”, R. XXXIV, nr 4, s. 609-648.

Nawrolska Grażyna. 2012. Początki Elblaga w świetle źródeł archeologicznych, Elbląg.

Penners Theodor. 1942. Untersuchungen über die Herkunft der Stadtbewohner im Deutsch-Ordensland Preussen bis in die Zeit um 1400, Leipzig.

Poliński Dariusz. 1996. Przemiany w wytwórczości garncarskiej na ziemi chetmińskiej u schytku wczesnego i na początku późnego średniowiecza, Archaeologia Historica Polona, t. 4, red. J. Olczak, Toruń.

Poliński Dariusz. 2007. Późnośredniowieczna ceramika tradycyjna. Problematyka identyfikacji $i$ datowania, [w:] Wybrane problemy wieków średnich, red. J. Olczak, Archaeologia Historica Polona, t. 16, Toruń, s. 77-89.

Rębkowski Marian. 1995. Średniowieczna ceramika miasta lokacyjnego w Kołobrzegu, Kołobrzeg.

Rębkowski Marian. 2001. Pierwsze lokacje miast $w$ księstwie zachodniopomorskim. Przemiany przestrzenne i kulturowe, Kołobrzeg.

Rzeźnik Paweł. 1998. Przemiany wytwórczości garncarskiej średniowiecznego Wrocławia w czasie wielkiej reformy miejskiej, [w:] Kultura średniowiecznego Śląska i Czech. „,Rewolucja XIII wieku”, red. K. Wachowski, Wrocław, s. 121-154.

Schultz Franz. 2011. Dzieje powiatu wejherowskiego i puckiego, thum. W. Sawicki, W. Szreniawski, red. R. Biskup, Gdańsk-Puck-Wejherowo.

Starski Michał. 2009. Uwagi o późnośredniowiecznej wytwórczości garncarskiej na Pomorzu Gdańskim, [w:] Wytwórczość w Polsce średniowiecznej i nowożytnej, red. J. Chudziakowa, Archaeologia Historica Polona, t. 18, Toruń, s. 75-95.

Starski Michał. 2015. Stan badań archeologicznych nad matymi miastami Pomorza Gdańskiego w późnym średniowieczu, „Archaeologia Historica Polona”, t. 23, s. 181-213.

Starski Michał. 2016a. Późnośredniowieczne wyroby garncarskie z Pucka. Studium małomiasteczkowej wytwórczości garncarskiej na Pomorzu Gdańskim, Warszawa.

Starski Michał. 2016b. Późnośredniowieczne naczynia gliniane z badań archeologicznych wschodniego bloku zabudowy przyrynkowej miasta lokacyjnego w Lęborku, „Światowit”, t. X (LI), fasc. B, s. 237-272.

Starski Michał. 2016c. Znaleziska importowanych naczyń ceramicznych w mniejszych miastach Pomorza Gdańskiego w późnym średniowieczu, [w:] Archeologia miast Pomorza w kontekście ziem polskich, red. G. Nawrolska, H. Paner, J. Piekalski, E. Trawicka, Gdańsk, s. 151-170. 
Starski Michał. 2017a. Uwarunkowania lokalizacji i rozplanowanie miasta lokacyjnego w Pucku, [w:] Puck. Kultura materialna małego miasta w późnym średniowieczu, red. M. Starski, Warszawa, s. $41-70$.

Starski Michał. 2017b. Podstawa źródtowa do badań nad kultura materialna późnośredniowiecznego Pucka, [w:] Puck. Kultura materialna małego miasta w późnym średniowieczu, red. M. Starski, Warszawa, s. 27-38.

Szulist W. 1970. Ważniejsze szlaki handlowo-komunikacyjne pólnocno-zachodniego Pomorza Gdańskiego w XVI-XVII w., „Zapiski Historyczne”, t. XXXV, z. 3-4, s. 129-236.

Ślaski Bolesław. 1916. Materjaty i przyczynki do dziejów nadmorskiego miasta Pucka oraz dawnej ziemi Puckiej, Warszawa.

Ślaski Kazimierz. 1948. Pomorskie szlaki handlowe XII i XIII wieku, „Przegląd Zachodni”, R. 4, I półrocze, s. 285-290.

Śliwiński Błażej. 1998. Dzieje Pucka w świetle najstarszych źródet pisanych (do 1308 r.), [w:] Historia Pucka, red. A. Groth, Gdańsk, s. 55-68.

Śliwiński Błażej. 2006. Rzeź i zniszczenie Gdańska przez Krzyżaków w 1308 roku, Gdańsk.

Śliwiński Błażej. 2009. Wydarzenia w Gdańsku i w okolicach w okresie od września do 12/13 listopada 1308 roku, [w:] ,Rzeź Gdańska” w świetle najnowszych badań. Materiały z sesji naukowej 12-13 listopada 2008 roku, red. B. Śliwiński, Gdańsk, s. 79-114.

Tandecki Janusz. 2000. Podziały administracyjne państwa zakonnego w Prusach, [w:] Państwo zakonu krzyżackiego w Prusach. Podziały administracyjne i kościelne w XIII-XVI wieku, red. Z. Nowak, R. Czaja, Toruń, s. 19-28.

Trzeciecki Maciej. 2009. Stare i nowe w garncarstwie wczesnośredniowiecznego Płocka, [w:] Stare $i$ nowe $w$ średniowieczu. Pomiędzy innowacja a tradycja, Spotkania Bytomskie VI, red. S. Moździoch, Wrocław, s. 187-228.

Trzeciecki Maciej. 2016. Ceramika Płocka. Między XI a XIX wiekiem. Studium archeologiczne, Warszawa.

Trzciński Łukasz. 2011. Badania archeologiczne prowadzone w Chojnicach przy ulicy 31 Stycznia 8, „Baszta”, nr 11, s. 99-122.

Walenta Krzysztof. 2002. Badania wykopaliskowe przy ulicy Szewskiej-Podmurnej w Chojnicach, [w:] Chojnice i Pomorze Wschodnie w średniowieczu, red. K. Walenta, Chojnice, s. 35-64.

Walenta Krzysztof, Trzcińska Krystyna, Trzciński Maciej. 2000. Nowe Miasto w Chojnicach w świetle badań wykopaliskowych, [w:] Archeologia et Historia, red. L. Kajzer, Łódź, s. 403-420.

\section{Puck i Lębork. Two models of pottery production development in small towns of Gdańsk Pomerania in the late Middle Ages}

The paper explores the characteristics of the pottery production in two urban centres of Gdańsk Pomierania - Puck and Lębork. The comparison of these towns shows different processes of the development of the local pottery in the first period after their establishment (from the 1340 s to the half of the fifteenth century).

In Puck, the traditional ceramic production, which was the continuation of the local early medieval craft, coexisted with the one brought by the settlers arriving to the newly founded town. In Lębork, however, only the latter situation was observed. The analysis of the both models of the local pottery production's development brings also the question if the discussed cases are the individual phenomena or if similar patterns can be traced in the history of other urban centres in the region.

In the paper, only the initial observations are given, as the insufficient research on the pottery production from the other towns makes providing definite conclusions impossible.

Translated by Maciej Radomski 